\title{
The Political Economy of Globalization and Possibilities for Regional Economic Development in Africa
}

\author{
Kunle Ajayi \\ Department of Political Science, University of Ado - Ekiti, P.M.B. 5363, Ado - Ekiti, Nigeria \\ Telephone: +234-8036672255, E-mail: kunleajayi566@yahoo.com
}

KEYWORDS Corruption; development; globalization; good governance; market economy; political economy and privatization

\begin{abstract}
Globalization, as a new concept for the universalisation of capitalism and a market driven strategy for development, has not enhanced socioeconomic development in Africa. The marginalization of Africa in the globalized free market economy in terms of both contributions and benefits, raises some problematic questions - Is Africa globalizing? Can globalization ginger up development in Africa? Beside marginalization from global market benefits, Africa is technologically backward. Economic development powered by industrialization is made difficult for lack of enabling capital and critical infrastructure. Mass poverty, deepened official corruption, pervading intrastate conflicts and civil wars, and lack of focused and people-oriented leadership pose serious barriers to development in the continent. Over-dependence on Western financial institutions for development capital in-flow merely assures and consolidates vertical economic integration and hierarchical relations between Africa and the West in ways absolutely favourable to the latter and promotive of a grand stage of imperialism. Globalization can, therefore, be described in the Marxian parlance, as the highest phase of capitalism. The problematic concerns of the study, therefore, are one, to examine the fundamental motives of the globalization paradigm, Two, evaluating African marginality in the benefits of a globalized market economy. Three, investigating the forces which hamstrung Africa in the globalized race. And four, examining the challenges posed by African marginality, and strategizing on how the region can overcome the risks of, and benefit significantly from, globalization.
\end{abstract}

\section{INTRODUCTION}

The globalization paradigm is basically a Western construct for the integration of world markets. The West has presented globalization as a market-driven strategy for development. The International Monetary Fund (IMF) and International Bank for Reconstruction and Development (IBRD) particularly described globalization as a principle meant to "rapidly develop and create a dense network of interconnections and interdependencies that characterize modern social life" (Oke, 2003: 22). In essence, globalization is aimed at the reduction of poverty and enhancement of global cooperation for universal economic growth and development.

Globalization has so far had little effect in turning around the fortunes of Africa, a region acclaimed to be the poorest and the least developed in the world (Onimode, 2000: 164; UNCTAD Report, 2004). African countries have since the 1970s implemented strong macroeconomic policies and structural reforms as dictated by the Western financial institutions, but without significant benefits to the continent. The problematic questions, therefore, are: What are the fundamental motives of globalization? In what ways is Africa marginalized and deprived from benefiting from a globalized market economy? What are the forces working against the continent in the globalized race? What are the challenges posed to Africa by its marginalized status in a global market-oriented economy? How can Africa benefit significantly from globalization? The concern of this paper is to provide responses to these problematiques of globalization. In an attempt to do this, the paper is divided into six sections. Section one is the introduction. Section two examines the concept and components of globalization. Section three interrogates the problematic question: Is Africa globalizing? Section four investigates the limitations of the African continent in the globalized market economy, while section five suggests the leeway for Africa to attain regional economic development capacity and benefits from the global economy. Section six is the concluding remarks. One believes that for Africa to benefit significantly from the globalized world economy, it must structurally transform from its present status of net primary producer and exporter to industrial producer and exporter. 


\section{CONCEPT AND POLITICAL ECONOMY OF GLOBALIZATION}

Globalization is construed as the increasing world wide inter-dependence of states and people. It has also meant the growing openness of countries particularly as regards the three critical aspects of globalization namely international trade, international finance and international investment. States' economies must open up for full private section participation. Globalization espouses the belief that economic growth and natural resources are limitless and that science and technology can fix all problems.

Technically, Scholte (2000: 15-16) conceptualizes globalization from four broad perspectives. The first conceives globalization as internationalization. Globalization in this way, lays emphasizes on cross-border relations among countries of the world with increasing international exchange and interdependence. The second is the interpretation of globalization as liberalization, meaning opening of market and removal of all restrictions on movements of goods and services including labour. Globalization, therefore, has as one of its focal points, free markets and unrestricted trading. The third views globalization as universalisation, a process that gives goods, services and labour a transnational character as national borders are no longer barriers. The fourth sees globalization as deterioration, meaning the growing irrelevance of social space, which is no longer considered absolutely in terms of territorial place, distance and borders. Held et al. (1999: 16) equate this latter perspective with a process, which embodies a transformation in the spatial organization of social relations and transactions.

The Marxian perspective interprets globalization to be synonymous with Westernization or modernization, a process of spreading capitalism across the world. Globalization is therefore equated with colonization and imperialism. Friedman (2000: 113) presents a much more informative explanation of globalization. He sees globalization as the "integration of capital, technology and information across national borders - uniting Brazilian peasants, Indonesian entrepreneurs, Chinese villagers, and Silicon Valley technocrats in a single global village".

Friedman (Ibid, 8-9) also identifies the contradistinctions between globalization and other systems. The over-arching feature of globalization is integration emphasizing the interwovenness and interconnectedness of place. The driving idea behind globalization is freemarket capitalism implying the more a state allows market forces to rule, the more its economy is opened to free trade and competition, and the more efficient and flourishing its economy will be. A rider to this feature is that globalization has its own set of economic rules including deregulating and privatizing the economy in order to make it more competitive and attractive to foreign investment. Friedman (ibid) compares globalization with the cold war system. According to him, the most frequently asked questions during cold war era was: "How big is your missile?" While its defining document was "The Treaty". In case of globalization, the most frequently asked questions are: "To what extent are you connected to everyone?" And the defining document of globalization is "The Deal". Globalization is predicated on super-advanced telecommunication information system as manifested in the all-pervading influence of the web. Revolution in the technology of communication actually propels and assures the globalization of world markets. Principally, satellite television, fibre-optic telephony system, the computer, the internet and microchip, which are referred to as the defining technologies of globalization, have enhanced urban-urban, rural-urban, and rural-rural communication around the world with unparalleled efficiency than ever known. These super-hitech facilities have reduced the world to a mere global village or global neighbourhood. Globalization has therefore ushered an electronic global economy, which is qualitatively a new and higher stage of market economy and liberalization.

Globalization has a wide range of components but the most prominent are the economic, political, social, cultural, environmental, ecological and spiritual dimensions. Globalization contains a holistic world-view. The economic dimension of globalization will only be addressed here.

The economic component of globalization revolves around the IMF and IBRD's political economic frameworks consisting of free trade, deregulation and liberalization of the market. The component also emphasizes the macro-economic indices such as inflation, foreign exchange and interest rates. The political economic framework embodies in its entirety the components of the Structural Adjustment Programme (SAP). 
Privatization aims at de-investing of public enterprises of government control and management, and consequently be left to private sector participation and control. Liberalization policy is to open up the economy without placing hindrances to market operations and competition, and removing any barriers to free flow of goods, services (including travels, and insurance etc), technology, communications and ideas.

Globalization is supposed to bring about a more prosperous world. Has globalization really solved world problems? Is it a cure or a curse? Responses to these questions have produced two distinct schools of thought. Globalization protagonists have viewed it as a solution to world problems. Amartya Sen, a Nobel Prize winner in Economics, believes that globalization has enriched the world scientifically and culturally, benefited many people economically and offer enormous potential to eradicate poverty in the 21st Century (Human Development Report, 1999).

In this way, globalization is seen as providing the necessary conditions for abolishing world poverty and ushering a world of prosperity and progress. In the same vein, Martin Wolf described globalization as "the great economic event of our era" that brings "unprecedented opportunities to billions of people throughout the world" (Awake, 2002: 3). Globalization has enhanced the interchange of ideas and the frequency of interactions among peoples of the world. Friedman, (op. cit) believes that frequent interactions, exchange of ideas and growing interdependency relations have provided increasing incentives for not making war, while it increases the cost of attempts to engage in war now than ever before. The frequency of interactions has also fostered the potential for improving global solidarity (Awake, op. cit., 4).

The antagonists of globalization have a differing view. They largely perceive globalization as inimical to economic and human development as it has failed to improve the living standard of average citizens in the developing world. It is argued that, globalization has widened the gap between the "haves" and "have-nots", between the rich and poor peoples and states of the world. According to Aaron (2001: 20), the exchanges brought by globalization have meant stupendous wealth for a few countries and wrenching poverty for the majority of mankind. It has enabled the concentration of global wealth in fewer hands and countries. Environmentalists criticized the globalized market economy for paying greater interests to profits than in the protection of the environment (Awake, op. cit. 4). Oyebode (2000: 205) summarizes the adverse effects of globalization by submitting that:

Globalization is merely a new term for an old phenomenon - imperialism. While the rich, industrialized countries are happy with and rejoice in globalization, it should be seen as serving to entrench the skewed terms of trade between the North and the South, based on the historical lopsided international division of labour which sentenced the peripheral parts of the world economy to the labyrinths of poverty and underdevelopment while the metropolitan countries continue to bask in affluence, power, influence and privilege.

Increasing poverty and economic - downturn being experienced by most non-Western countries and people, therefore, continued to question, and raise doubts about the potency of the prescriptions of the free market institutions. And for the ill effects of globalization, antiglobalization groups and activists have sprung up, mostly in the Western world. Such groups in the United States include; Anti-Capitalism Protesters; and, Abolish the Bank organization. These groups held a conference in 2004 at Bombay, India where about 100,000 delegates from 130 countries were in attendance (The Editor, 2004: 11) The Conference sought world alliance against globalization.

\section{IS AFRICA GLOBALIZING?}

There is the need to examine the extent to which Africa has been involved in the globalization trends. African states have been much more engaged in the economic aspects of the globalization process particularly regarding the implementation of the Structural Adjustment Programme (SAP) of the IMF and IBRD.

The structural framework includes programmes such as: trade liberalization; privatization; devaluation of the currency; external debt management; and, removal of subsidies among others. Each of these standby arrangements has implications for the economies and people of the region.

Trade liberalization requires the states to throw open their borders and ports to all kinds of goods and services including labour without any tariffs or restrictions. Consequently, African 
markets have been reduced to dumping grounds for all kinds of goods with very low qualities. Used articles ranging from vehicles to electronics, utensils and wears have flooded the markets (The Editor, 2002a: 35). To these extents, African economy has been reduced to a cargo economy implying an economy that deals mainly with imports and little or no exports. In Nigeria, the dumped second-hand articles are locally called Tokunbo (Ajayi, 2002: 126). Privatization has led to the selling off of most public enterprises engaged in providing basic services such as electricity, treated water, postal, telephone and ports services. The enterprises are now being controlled by the private sector, which operates purely on profit maximization. Prices of the goods and services have become exorbitant and therefore not affordable to the masses. Beside the basic service providing public enterprises, in Nigeria, government is under persistent IMF pressure to privatize its currency and securities printing company without considerations for the security implications. Generally, privatization of state-owned companies has worsened the standard of living of the masses due to unaffordable prices of goods and services, and had led to unemployment as it causes as much as $75 \%$ job cuts and pauperization of retirees of the companies as they often lose all pension and retirement allowances hitherto enjoyed (Ugwu, 2002: 16). In addition, privatization widens the inequality gap in the society because only the few rich in the society and top government officials and their allies and clients are financially empowered to acquire shares of the privatized agencies.

Currency devaluation ensures the declining value of African currencies vis-a-vis the Western hard currencies namely the Pound Sterling, Dollar and Franc. Devaluation makes the prices of African export commodities such as cocoa, coffee, cotton, hides and skin, banana, rubber and others to be ridiculously cheap in the world market (Okwuofu, 2004: 28; Onimode, 2000: 113). Inversely, the prices of imported Western goods and services are constantly on high side. While low prices of export leads to less revenue to the state, the accompanied inflation of devaluation makes living conditions more difficult for most citizens in the continent (Ajayi, 2004: 168). Removal of subsides on food, fuel, agricultural in-puts including fertilizer, insecticides and seedlings have the same effects on the poor people of Africa as devaluation. Removal of subsidies implies cessation of official support and cushion effect measures on the goods and services concerned. The products and services are therefore left to the forces of supply and demand to determine the actual prices. Ironically and advertently, the forces of supply and demand have only one end rule in Africa - constant high prices, consequently, it is believed that "whatever price goes up in Africa will never come down". In its entirety, it may be reasonable to allude that the adjustment and austerity measures of the global market economy have only made Africans' condition of life worse off. Increasing devaluation of human worth in Africa has, therefore, put to doubt the efficacy of the market-oriented policies of liberalization and privatization to raise the standard of life in Africa.

Africa has, therefore, globalized to the extent of implementing the IMF and the Bank imposed structural and free market reforms and the World Trade Organization (WTO) policy of tariff liberation for a freer and more open market with asymmetric advantage in favour of Western capitalist states. Capitals and some cities in the continent have been connected to the Global System of Mobile (GSM) telecommunication and the Worldwide Web. Limited commerce and banking operations are being conducted electronically between the capitals and the rest of the world. Within these spheres, globalization processes in Africa can be termed as "one-way" as the continent is merely reacting to responses, and adopting information technological devices, from Euro-America without being able to initiate and generate its own or penetrate Western markets with its goods and services as required by the free and open market principles of WTO and IMF.

\section{CONSTRAINTS TO GLOBALIZATION IN AFRICA}

Globalization, as an economic strategy for generating worldwide wealth and prosperity, has limited application and acceptance in Africa. While the goal of a globalized market-oriented and competitive economy may be these stated aims, Africa as a whole lacks the capacity and the enabling local and external incentives and conditions to convert its abundant potentials to advantage for the purpose of attaining significant dividends from a globalized economy. A cursory 
interrogation of the situation in Africa reveals the following limitations:

Mono-cultural Economy and Technological Backwardness: African states' economies are characterized by heavy reliance on primary exports (Magbagbeola, 2004: 158). And in most cases, the economies are mono-cultural with foreign exchange earnings derived mainly from a primary export. As instances, petroleum is the mainstay of the Nigerian, Libyan and Gabonese economies, while Ghana relies on Cocoa, Cote d'Ivoire on Coffee and South Africa, gold (UNCTAD Report, 2004).

Overall, the poor technological and scientific capacity of Africa accounts for its low production level in the global economy. Its production level stands as low as $0.02 \%$ of the global total as against the functional minimum of $1.5 \%$, and this is believed not adequate in serving the needs of the region (Randle, 2004: 32).

The detriment aspect of the mono-cultural economic character of the region is that while these raw materials are being produced in Africa, Western markets, and coincidentally, the net consumers of the primary materials determine the selling prices. Fixing of the prices are not subject to the market forces proclaimed by Western financial institutions but based on the whims and caprices of Western buyers at the New York, Tokyo, London and Paris' markets. Africa lacks the capacity to fix the prices of its products because it does not consume them in industrial quantities. The West, which consumes them, also controls the markets. Therefore, the inability to consume what it produces is a major blow to economic prosperity in Africa. The problematique, therefore, is: Why can't Africa consume its products? Africa lacks the technological and industrial capacity to convert its raw materials to exportable manufactured products, which can earn more foreign exchange revenue than when sold raw. Besides being unable to process the raw materials into manufactured goods, the continent also lacks storage facilities, thereby prompting wastage and panic selling at give-away prices. In all, the international division of labour, which assigns primary production to Africa, is a major barrier to her attempts at economic development.

Unfavourable World Market Environment: Western markets have not provided equal trade opportunities for Africa and other Third World goods and services. Despite the glamour accorded IMF and WTO free and open trade policies, Western markets still discriminate against primary and manufactured goods from the developing world as a whole. For instance, the United States in March 2002 imposed 30\% tariff on steel imports in order to protect its own local industries from foreign competition and eventual collapse, and to save the jobs of its citizens (Arowolo, 2002: 15). Specifically concerning Africa, its cocoa beans are sold to Europe on a duty-free basis, but when it sells its manufactured cocoa butter and chocolate, they are subjected to tariffs (The Editor, 2002b: 22). This discriminatory trade policy, apart from hampering the development of domestic processing industries, leads to annual dwindling shares for Africa in world exports. For instance, the continents $5 \%$ share of world exports in 1980 fell to $3 \%, 2 \%$ and $1.2 \%$ respectively in 1985,1990 and 1996 (Ajayi, op. cit. 97). The decreasing export shares induced among other factors but mainly by Western trade restrictions, yearly leads to the loss of about $\$ 350$ billion to Africa (The Editor, 2002b, op. cit.). In addition, Africa is losing $\$ 68$ billion yearly to liberalization and other globalization modes due to the unequal implementation of the Uruguay Round Agreement and unequal power relations within the negotiating framework of the WTO (Adeloye, 2003: 20). The $\$ 68$ billion loss represents $21 \%$ of the continent's GDP (ibid.). Cumulatively, African earns an insignificant $1.3 \%$ of world income compared to $77.9 \%$ of the trio of North America, European Union and Japan or $78.5 \%$ of total rich countries (Onimode, 2000: 164). The implication for socioeconomic development is that the continent earns only meager revenue, which is not sufficient for any meaningful industrial and human development projects.

Lack of Enabling Capital and Poor Aid Flow: It has been established that African generates very low income from exports due to the cheapness of its raw materials and the selective discriminatory openness of world market to African goods. Initiatives towards industrial development and poverty reduction in the continent have suffered setback because of paucity of funds. The New Partnership for Africa's Development (NEPAD), which requires \$64 billion yearly to reduce poverty by half among Africans (NEPAD, 2001: 147) has not taken off due to lack of funding. Attempts to mobilize resources to fill the local revenue gap have not yielded sufficient 
dividends to meet up. The eight major industrialized countries (G-8) including Russia, granted $\$ 6$ billion to NEPAD as Overseas Development Agency (ODA) aid (Akintunde, 2003: 8). This is a paltry sum considering the advanced level of industrial and economic development of the eight countries coupled with the fact that they earn as much as $78.5 \%$ of world income. In a way, the aid system, a cardinal principle of the Bretton Woods arrangements, has not been favourable to Africa for the instigation of economic and industrial development in the continent.

The debt option becomes an attractive alternative to African countries to mitigate effects of poor earnings and low ODA support. Consequently, Africa as at 2000 owed $\$ 350$ billion externally. Generally, foreign aid and loans accounted for $42.5 \%$ of Africa's total capital inflows and for very poor countries like Mauritania and Mali, the figure could be as high as $80-100 \%$ (Ajayi, op. cit, 142). The adverse effect of Africa's debt burden is mostly felt in its servicing the loans. The continent pays creditors as much as $\$ 10$ billion annually only to serve the loans, while Nigeria alone pays $\$ 1.5$ billion yearly (Odenyi, 2002: 1). The devotion of as much as $50 \%$ of African states' Gross National Product (GNP) to debt servicing on the average, a figure which goes up to as much as $70-90 \%$ on the country - to - country analysis (Ajayi, op. cit, 142) certainly divests them the financial capacity for any sustainable development particularly regarding industrialization and human development.

Low Level of Telecommunication Facilities: Globalization is necessarily propelled and sustained by Information and Communication Technologies (ICT). The new revolution in information technology which combines the use of computers, telecommunication and satellite television ensures the rapid inter-connectiveness of world markets and provides adequate knowledge of market and business opportunities timelessly. Private communications and business transactions including capital transfers are easily and quickly carried out.

The use of ICT in Africa is very poor. Besides lacking the technological know-how to produce its own ICT, mass abject poverty has denied most Africans the advantages of the super-advanced information technology. It is estimated that only eighteen mainline telephones exist per 1000 people in Africa, compared with 146 for the whole world and 567 for Western countries (NEPAD, op. cit: 4). The figure is worse when it comes to cellular phones, there exists 0.02 cell line per 1000 people (Ajayi, op. cit, 187). Access to the Internet is also poor. In Nigeria, for instance, only $10 \%$ of youths have access to Internet, compared to $65 \%$ in America. Besides, majority of academics in the nation's ivory towers has no computers and Internet facilities. Generally, Africa generates a meager $0.4 \%$ of the contents of worldwide web, while the computer culture is at its most primary level as 1 to 3 computers serve 1000 people in the continent (United Nations, 1999: 17-19). This is a sharp contradiction to the dynamic use of these facilities in Britain and other Western world where the use of internet, GSM telephone and text messages has been up by $380 \%, 177 \%$ and $400 \%$ respectively (news@ sky.com, 12th August, 2004). The low use of these advanced telecommunication technologies in Africa cannot but be expected in a continent where as many as 340 million people or half of the population, live on less than \$1 per day (NEPAD, op. cit: 54 ) coupled with over $70 \%$ illiteracy level. Overall, inadequate ICT facilities are a bane to globalization in Africa as it constrains foreign investment and global business connections.

Protracted Conflicts: Post-independence Africa has been de-devilled by the scourge of war and violent conflicts. There is no sub-region in Africa that has not experienced civil wars. Statistically, according to Mario Machungo, Chairman, African Leadership Forum (ALF), out of the 35 genocide cases recorded in the world, 11 occurred in Africa (Ogbu, 2002: 3). The most worrisome aspect of the conflicts is their protractedness and intractability to the extent that many have lasted as long as ten years (e.g. Liberia, Sierra Leone, Algeria, Somalia and Burundi Civil Wars), while some others lasted up to twenty years (e.g. Sudan and Angola).

The perennial conflicts do not provide a conducive, peaceful and secure environment needed for local development and foreign investment. Even agricultural production is made difficult due to lack of social and psychological stability arising from the wars. Consequently, in addition to loss of lives and property, Africa loses about $\$ 10$ billion yearly to conflicts (Ibid.).

Poor Leadership and Bad Governance: Africa is abundantly endowed with natural resources including agricultural materials, 
minerals and forest resources. The continent is also endowed with human resources. However, the continent has the misfortune of being governed by leaders that lack the competence, vision, direction, purposeful and public-inspired spirit. Sit-tight attitudes, greed, corruption and private interests have driven leadership in the continent. This is to the extent that leadership can be seen as synonymous with corruption in Africa. The problems of private accumulation and incompetence often lead to lack of peopleoriented policies, while attempts to unseat the leadership, which may be considered as overstaying often lead to violent conflicts and civil wars. Most leaders in Africa are inclined to the embezzlement of state resources. According to the United Nations, Africa has lost $\$ 400$ billion to corruption, while about $\$ 100$ billion has been stolen from Nigeria alone by its leaders (Amokeode, 2004: 1). For instance, General Sani Abacha, Nigeria's Head of State (1993-1998) and his immediate family were alleged to have stolen from public coffers, a whopping sum of $\$ 5$ billion (Olasanmi, 2005: 3). The implication of kleptomaniac leadership is the stifling of development due to shortage of funds.

\section{POSSIBILITIES FOR REGIONAL ECONOMIC DEVELOPMENT}

Africa possesses the potentials and prospects for tapping the accruable benefits of a globalized market economy if the necessary conditions can be locally harnessed and externally engineered. The following suggestions therefore suffice:

Diversification of the Economy: Africa is basically an agrarian and raw materials supplier economy. Individual analysis of the states, as pointed out earlier, indicates that their economies are mono-cultural having relied on just one major raw material for foreign exchange earnings. The raw materials are usually subjected to vagaries of world prices.

Besides, as earlier stated, Africa has no control over the prices of its raw materials as they are fixed in the Western markets in Paris, New York and London. The ill effect of all these is that, African economies are prone to perennial economic instabilities as a response to the instability in the commodity markets and prices of its products. Again, the mono-cultural character of the economies makes it possible for the Western world to hold raw material producers to ransom as they can decide to buy or not to buy. If they decide not to buy, it means causing glut of the products in the world market and consequently, a fall in their prices. Such unstable market's condition makes fiscal planning and developmental policies difficult to realize. Proselytizing the economy is therefore an imperative for African States.

The economies must transcend primary production to a manufacturing economy. Africa must invest significantly on industrialization and the starting point of this is the radical reformation of tertiary education in the continent for technological transformation through proper funding. Most countries in the region including Nigeria have not acknowledged the correlation between research and development, because most African leaders lack tertiary education. For instance, a university graduate has never ruled Nigeria. Acquisition of a industrial-based technology by the continent will afford the minimum production base. According to the UNCTAD Report, (op. cit), possession of the minimum base will increase the supply capacities of states and thereby enable them to take the advantage of export market access preferences. In essence, converting the regimes, raw materials into finished industrial goods that can be marketable in international markets will earn it more foreign exchange. The mineral sector holds a lot of promise for the technological transformation of the continent. The organized private sector has the burden of transforming the economies and, therefore, it must be provided the necessary conducive investment climate especially a peaceful environment.

Limited Protectionist Policy: African economies and markets are too weak to be totally open and free for all trades. The weakness of the markets makes them to lack any competitive resistance and shock absorber, consequently, emerging local entrepreneurs are easily sent out of market circulation by goods from stronger markets. African states either individually or collectively need some protectionist policies to improve local manufacturing and to save jobs. The international monetary system and the WTO must acknowledge the peculiar nature and emerging character of African economies and thereby grant the region protectionist concessions devoid of retaliatory measures.

Filling the Infrastructural Gap: Poor infrastructural base is the major barrier to industrial 
development in Africa. Basic infrastructure such as roads, waterways, electricity, energy and telecommunication facilities are at its poorest level in the continent. Africa consumes the least energy in the world, implying low industrial growth. No nation or continent can attain economic growth and development without affordable and reliable infrastructural services. Therefore, any attempts at significant economic leap in Africa must first aggressively address the structural gap in infrastructure. It should be noted that in some countries like Nigeria and Ghana, the structures are there, but the problem is that of lack of maintenance culture. Virtually, all social and industrial infrastructure in Nigeria have collapsed including oil refineries, electricity authorities, public telecommunication carriers, water supply and waste management, due to lack of maintenance. The private industrial sector in the country has been spending a lot as over-head costs on electricity and energy. Consequently, unbearable over-head costs have triggered factory closures and capital flight. For instance, between 1986 and 1991, Nigeria recorded capital flight amounting to $\$ 19.73$ billion and disinvestment by some 200 foreign companies between 1993 and 1995 (Fiakpa, 1995: 36-37). In many cases, the infrastructural facilities are there but lacking in maintenance. What, therefore, needed is regular turn-around maintenance to ensure efficient performance of the facilities. This will in turn entices foreign investors and at the same time induces productivity at the informal sector of the economy, which is the largest sector of the African economy.

Fair Trade Policies and Greater Access to Euro-American Markets: Diversification of the economies to manufacturing may not yield the desired benefits unless African countries' exports have greater access to the strong markets in Europe and North America. Africa as a collectivity under the aegis of African Union needs to agitate for fair trade policies and nondiscrimination against its products in the advanced markets. Providing parity between developed countries and African goods by making the world market equally accessible to African exports is a major key to the region's development. Alternatively, Africa should adopt a counter-balance strategy by implementing a selective or limited open market for Western goods as America itself does.

Aggressive Technological Development:
Converting from raw material economy to manufactures may be unrealistic unless drastic steps are taking to reverse the technological backwardness of the region. Considering the fact that nothing has changed despite decades of advocacy for transfer of technology by the advanced world to the Third World, Africa has to look inward for technological development initiatives. The starting point must be an aggressive investment in science education and developing the African indigenous technology. Africa has a lot of potentials in achieving this as it has the skills and intellectuals that can achieve the expectation. African scientists, technologists and engineers abound in Diaspora especially in the developed world. African leaders need to curb the loss (brain-drain) of African intellectuals to the West by providing the necessary socioeconomic, and political security conditions for African professionals to stay at home, and to recall those in greener pastures abroad in order to develop the continent technologically. Investing in industrial technology should simultaneously include initiating and developing the ICTs sector. ICTs development will rapidly make known to the world the potential opportunities available in African markets and thereby trigger its economic development.

Consolidation of Regional Trade Agreements: Sub-regional economic integration such as the Economic Community for West African States (ECOWAS) and Southern Africa Development Committee (SADC) should serve as platform for a greater and functional regional economic integration in the continent. The trade agreements of sub-regional organizations need to be fully implemented so as to remove all regional barriers to exchange of goods and services including skilled labour. Trade agreement must particularly lay emphasis on manufacturing goods so as to encourage local production, while the crazy culture for Western manufactures must be discouraged among the nationals of each state. Mobilization of African population to embrace their own goods should be high on the agenda of the African Union. When free flow of goods and services is fully operational at the sub-regional levels and local consumers develop taste and passion for them, then, a similar market and attitudinal transformation can take place at the overall regional level. In a way, engineering globalization (trade liberalization) first at subregional and regional levels and harnessing the 
advantages of such effort may provide the needed competitive platform to meet the challenging standards and risks of the globalized market economy.

\section{CONCLUDING REMARKS}

This study is of the submission that globalization has not yielded the intended dividends in Africa. Its goal of open and competitive market remains a mirage. And indeed, it may have tied together world economies but its benefits are skewed against Africa. Structural reforms imposed on the economies by the Bank and IMF have only worsened the human condition in Africa, as cost of living becomes unbearable. The globalized market economy has reduced African market to dumping site for all kinds of junk goods thereby killing local industries, which lack capacity for competition, and consequently leading to job loss and unemployment. The negative contributions of globalization in Africa, therefore, imply that the globalization institutions as represented by the IMF, IBRD and WTO are anti-African develop-ment.

For Africa to play active role in, and benefit significantly from, globalization, the continent needs to address two levels of barriers - internal and external forces, that are limitations on attaining the expected advantages. Internally, African economies need to undergo rapid structural economic changes by transferring from net raw material producers and exporters to industrial producers and exporters. The region's leaders must acknowledge that no raw material based economy can either contribute or benefit from globalization. In a way, the hitherto unfavourable international division of labour has to be deliberately tinkered with by Africa. This is achievable through aggressive investment in industrial technology so as to transform the regions from import - driven to export - driven economy and make it have capacity for global market competitions. Protracted conflicts and the prevailing conditions of insecurity across the continent which deny, constrain and frustrate possibilities for national and regional development must be resolved and avoided as high priority so as to provide conducive milieu for innovative and sustained development. Infrastructural facilities serve as the catalysts for private sector efficiency. The appalling situation of the infrastructural sector, which is frustrating productive industrial performance and investment in Africa needs urgent rehabilitation. The continent's deficiency in maintenance culture must be reversed.

Externally, for globalization to be meaningful to Africa as an economic modus operandi to facilitate the reduction of inequalities between the developed and the under-developed worlds and to alleviate poverty among peoples of the world, it must of necessity provide a level plain ground for all nations to operate. In doing this, equal access must be granted all nations to international markets without any forms of discrimination. Discrimination against goods from Africa is definitely anti-globalization principles. The developed world also has to do much more in contributing to African development by increasing aid flows to the region.

Similarly, foreign investors (Transnational Corporations - TNCS) have important role to play in moving the continent forward. This they can do by stepping up their investments in Africa. The TNCS must shift significant investment attention to Africa like they are currently doing to China, which has become the labour pool of preference for global manufacturing.

Lastly, globalization has to be seen as supportive of the democratization process in Africa. Poverty is anti-thetical to democracy. The new democracies in Africa need consolidation and sustainability. The opportunities and benefits of globalization need to be democratized for the purpose of people's socioeconomic welfare worldwide. The economic capacity strengthening needs for democracy and good governance in Africa, therefore, remains a major challenge to globalization.

\section{REFERENCES}

Aaron, K.K. 2001. "Playing Without the Kits: Towards a Beneficial Participation of Africa in a Globalized World." Annals of the Social Science Academy of Nigeria, Number 13, January - December, 20.

Adeloye, L. 2003. "Africa Loses $\$ 68$ billion to Liberalization, Globalization yearly." The Punch, Lagos, The Punch Newspapers, March 26.

Ajayi, K. 2002. International Administration and Economic Relations in a Changing World. Ibadan: MAJAB Publishers.

Ajayi. K. 2004. "Globalization and the International Monetary System", in Kunle Ajayi and B. Ayodele (eds.) Perspectives on Democracy and Development in Post-Military Nigeria. Ibadan: Julius and Julius Associates.

Akintunde, O. 2003. "G8 Grants NEPAD \$6 billion aid." 
The Punch, Lagos, The Punch Newspapers, March 6.

Amokeodo, T. 2004. "Africa loses \$400bn to Corruption - UN." The Punch, Lagos, The Punch Newspapers, December 31.

Arowolo, A. 2002. "Limits of Globalization." The Punch, Lagos, The Punch Newspapers, April 4.

Awake. 2002. "Globalization: Curse or Cure?" May 22: 3-4.

Fiakpa, L. 1995. "Anglo-Nigerian Business; a don quicto affairs." Tell, Lagos, Tell Magazine, August 14.

Friedman, T.L. 2000. Understanding Globalization: The Lexus and the Olive Tree, New York: Anchor Books.

Held, D., G. McGrew, D.Goldblatt and J. Perraton. 1999. Global Transformations: Politics, Economics and Culture. Cambridge: Polity Press.

Human Development Report, 1999. cited in Awake! "Globalization: Curse or Cure?" May 22, 2002: 4

Magbagbaola, N.O. 2004. "Globalization and Nigeria's Economic Development:A Critical Assessment", in K. Ajayi and B. Ayodele (eds.) Perspectives on Democracy and Development in Post-Military Nigeria. Ibadan: Julius and Julius Associates.

NEPAD. 2001. The New Partnership for Africa's Development, Abuja, Sections 4 and 147. News@sky.com 12th August, 2004.

Odenyi, P. 2002. "\$3.3 Billion Debt Servicing Arrears Recorded." The Comet, Lagos, The Comet Newspapers, August 29.

Ogbu, C. 2002. "Africa Loses $\$ 10 b n$ to Conflicts." The Punch, Lagos, The Punch Newspapers, April 3.

Oke, B. 2003. "Workers Fault full embrance of globalization." The Punch, Lagos, Punch Newspapers, January 15.
Okwuofu, O. 2004. "Prices of edible oils crash in world market." The Comet, Lagos, The Comet Newspapers, July 2.

Olasanmi, K. 2005. "Mohammed Abacha must be prosecuted, says Fed. Govt." The Comet, Lagos, The Comet Newspapers, March 10.

Onimode, B. 2000. Africa in the world of the 21st Century. Ibadan: University Press.

Oyebode, A. 2000. "External Imperatives", in T. Oseni, A.Sambo and K. Samuel (eds.) Nigeria: Path to Sustainable Democracy. Lagos: Obafemi Awolowo Foundation.

Randle, J.K. 2004. "Design fault, terminal failure or miracle cure." The Comet, Lagos, The Comet Newspapers, May 19.

Scholte, J.A. 2000. Globalization: A Critical Introduction. London: Macmillan.

The Editor 2002a. "Oshiomole advocates knowledge of global economy." The Punch, Lagos, The Punch Newspapers, April 10.

The Editor 2002b. "Trade and Investment, Key to Development, says Africa Finance Ministers." The Comet, Lagos The Comet Newspaper, July 10.

The Editor 2004. "Anti-globalization Movement Seeks World Alliance against Bush." The Comet, Lagos, The Comet Newspapers, January 19.

Ugwu, E. 2002. "Privatization: Workers threaten to shut down the ports." The Punch, Lagos, The Punch Newspapers, May 23.

United Nations, 1999. Africa Recovery, Vol. 13, No. 4 December $17-19$

UNCTAD Report 2004. The Least Developed Countries Report (http//: www. unctad. org/en/pub/ps1/ dco2.en.htm) 